Frontiers: The Interdisciplinary Journal of Study Abroad

(C) Martha Johnson \& Anders Larsen

The work is licensed under the Creative Commons Attribution-NonCommercial-

NoDerivatives 4.0 International License.

Volume 32, Issue 3, pp. 51-71

DOI 10.36366/frontiers.v32i3.579

FORUM

ON EDUCATION ABROAD

\title{
Exploring the Potential of Cultural Drag
}

Martha Johnson ${ }^{1}$ \& Anders Larsen ${ }^{2}$

\section{Abstract}

This article illustrates the problematic nature of the use of intercultural, international exchange as the primary or singular mode of understanding the study abroad experience and proposes alternative ways of talking to students about their study abroad experiences. While the focus on cultural exchange may be a practical trope, it creates a clear understanding of them-versus-us in terms of values and behaviors. It also glazes over some central features of the postmodern study abroad experience. We argue that the study abroad can be understood through the metaphor of drag, i.e., the act of putting on a costume and performing an identity. "Cultural drag" gives students the opportunity to experiment and play with their identity and explore how their privilege may change depending on where and how they present themselves. The article examines the strengths and weaknesses of this metaphor and explores how to advise students so they have an awareness of the role of their body once they enter the experience.

\section{Abstract in Danish}

Denne artikel illustrerer problematikkerne ved at benytte interkulturel og international udveksling som den eneste eller primære måde til at forstå studerendes udenlandsophold. Samtidig foreslår artiklen alternative måder til italesættelse af de studerendes oplevelse. Branchens fokus på kulturel udveksling er praktisk da det etablerer en modpol de studerende kan spejle

1 UnIVERSITY OF MinNESOTA, MinNEAPOLIS, USA

2 DiS - Study AbRoAd in SCANDinaVia, Copenhagen, Denmark

Corresponding author: Martha Johnson, University of Minnesota, marthaj@umn.edu 
værdier og handlinger i. Dog ignorerer dette fokus centrale aspekter af det postmoderne udenlandsophold for studerende.

Denne artikel argumenterer at metaforen kulturel drag, altså at iføre sig et kostume og spille en identitet, kan kaste lys på de studerendes oplevelse. Kulturel drag giver de studerende mulighed for at eksperimentere og lege med deres identitet, samt at undersøge hvordan deres privilegier ændrer sig alt efter deres positionalitet og fremtoning. Artiklen undersøger styrker og svagheder ved føromtalte metafor og undersøger hvordan studerende kan rådgives før udenlandsophold så de bliver bevidste om deres krops performativitet.

\section{Keywords:}

drag, body, education abroad, study abroad advising

\section{Introduction}

This article attempts to show the problematic nature of the use of intercultural, inter-national exchange as the primary or singular mode of understanding the study abroad experience, as well as propose alternative ways of talking to students about the experiences they have while studying abroad. The article suggests that while the focus on cultural exchange may be a practical trope, as it creates a clear understanding of them versus us in terms of values and behaviors, it also glazes over some central features of the postmodern study abroad experience.

In this article, we argue that the study abroad experience can additionally be understood through the metaphor of drag, i.e., the act of putting on a costume and performing an identity. The term has previously been used in critical writing about theatre ${ }^{1}$ and in theoretical texts about language acquisition ${ }^{2}$. However, it has never been used deliberately in an analysis of the study abroad industry to our knowledge. While the metaphor of drag may initially sound superficial or simplistic, we argue that the term "cultural drag," avoids the essentialist narratives often used in the industry, as well as gives us an awareness of learning as more than just an intellectual venture. The metaphor of cultural drag recognizes that we do not have bodies, but that we are bodies, and that a defining characteristic of study abroad is the relocation of bodies. We argue that cultural drag provides students with the opportunity to

\footnotetext{
${ }^{1}$ For example: Arroyu, J., "Mirror, mirror on the wall": Performing racial and gender identities in Javier Cardona's "You don't look like."

' See: Wooten, Jennifer A., Cultural Drag: Theorizing the Performance of Non-native Spanish Teachers' Linguistic and Cultural Identities.
} 
experiment and play with their identity as well as a chance to explore how their privilege may change depending on where and how the present themselves. This disrupts simplistic beliefs that learning abroad can be standardized, quantified, and measured in purely intellectual terms, and intentionally undermines the notion of the authentic experience abroad. The article will examine the strengths as well as the weaknesses of this metaphor and explore how to advise students so they have an awareness of the role of their body once they enter the experience.

\section{Setting the Scene}

It is Friday at Vega Nightclub in Copenhagen. Way too many people are crammed into the room as a spotlight hits the stage. The hostess Megan Moore towers on to the stage in impressive platform heels and welcomes the audience with a strong Californian accent. While the audience believes that Meagan is American, she is in fact a regular guy raised in the suburbs of the Danish capital. Megan introduces the first act of the evening, Miss Harley Queen. She enters the space dressed in a short blonde wig and mimics Ellen DeGeneres as she moves her lips to a recording of a stand-up show. As the audience cheers her on the act of cultural drag continues.

The two queens on stage have not only been mimicking a gender, but also passed as American. This seems to be an extension of a larger cultural phenomenon. Nearly all pop music is performed in an American accent. An example could be The Rolling Stones who adopted a Southern blues voice or the K Pop band Bing Bang that mix English phrases sung with a strong American accent into their songs. The drag show, as well as the pop performances happen in venues where the audience is aware of the illusion. The spectator plays along and willingly believes in the gendered drag, as well as the cultural drag that just played out on stage.

As international educators we currently navigate a minefield of explosive ideologies. We encourage our students to integrate into the local culture, to be sensitive to local customs around dress and behavior, and to constantly reflect on the transformation of their identity. At the same time, we do not want them to commit the mistakes of the colonials of the past, who exotified locals, appropriated their culture and isolated themselves in gated communities ${ }^{3}$. The postcolonial cultural encounter is one that must be approached with great humility but perhaps also with irony. This is where the term cultural drag shows itself as useful. In order to understand how the drag show in Copenhagen relates to the experimentation with identity study abroad

\footnotetext{
${ }^{3}$ See: Ogden, Anthony. "View from the Verandah: Understanding Today's Colonial Student." Frontiers: The Interdisciplinary Journal of Study Abroad.
} 
students engage in, we first need to explore the Western constructions and performance of intersecting identities, and in this specific case, that of gender and that of national culture.

\section{Performance and Transgressions of Gender Identity}

Transgressing gender roles through dress and behavior is a phenomenon found in many cultural spheres, historically as well as in the present. The idea of gender bending is often seen as subversive, but it also hosts the potential of supporting a hegemonic cultural system. When visiting contemporary Bangkok Western tourists seek out specific bars, and later return to their respective countries with stories that draw on a narrative about effeminate Asian men that appear to be women. Here we observe how a transgression of gender helps support an existing narrative.

The phenomenon intersects with racial, identities and well as one that moves across taste systems and hierarchies of power. The transgression of gender draws attention to the construction of gender itself and helps us understand how it is constructed in a given context.

"Drag" is specific to a practice found in postmodern westernized societies. In its most traditional form, drag refers to a CIS gendered or biological gay man who through costuming and movement performs the role of the diva, often by miming to music, a so-called lip sync. Drag can however also encompass CIS women who dress as men (drag kings), trans people who dress as a character of either gender and many other variations.

The history of gender performance on the stage in the West is long and varied, dating as far back as ancient Greece. During Elizabethan times strict laws denying females the right to act on stage necessitated that roles to be played by male actors. Gender drag has remained a prevalent theatrical convention. From Lady Macbeth to modern British Christmas pantomimes, the performance of female characters by male actors is prominent and accepted in mainstream theatre. Similarly, female parts were sung by castratos in Early Modern European opera. Here we observe that the theatre was a gendered space and that the transgression of gender helped maintain a social order of male dominance in which the performativity of femininity was clearly prescribed.

Drag is a way for the performer to transform the appearance of their body through costuming in order to negotiate a normative identity, but also to have the privilege of removing the costume again. It is a way both a way to hide behind a mask that allows you to do things you usually would not be able to do, 
but also a way to command and control a gaze. ${ }^{4}$ While drag is performance, drag queens ironically use the term real or realness about performers who can emulate the opposite gender to an extent that the illusion seems complete. Realness draws attention to the constructed nature of the representation and questions hegemonic gender binary ${ }^{5}$. In short it is an embodied rejection of the supposed authenticity of gender identity. ${ }^{6}$

The suggestion of identity as a performed construct, particularly the female gender, has been explored in depth in cultural and gender studies theory. This dialogue continues to be primarily focused on gender and tends to focus on gender tropes from a white, Western, and bourgeois perspective. The term cultural drag similarly holds potential for negotiating social positions. This will be discussed later in this article.

When interrogating the performance of identity, the question of what differentiates masquerade and mimicry needs to be addressed. There is a primary distinction. While masquerade seeks to enhance or signify difference with an assumption of an underlying essentialism, mimicry denounces essentialism and focuses on fetish and elements of identity ascribed through cultural construction. In other words, mimicry acknowledges the role of cultural construction in the performance of identity.

In her book, Gender Trouble, the American scholar Judith Butler demonstrates how sex, gender and desire are fused in Western societies, and argues that gender is performative. Paraphrasing Nietzsche, she argues that there is no gender behind the act; that gender is simply the result of a continuous series of acts, rather than an essence that defines the person. Gender is thus produced by social agents, rather than being implicit or a static essence contained within the individual. ${ }^{7}$ Gender is one aspect of a tripartite system also consisting of biological sex and sexual desire. Butler demonstrates how the three aspects fuse in that consists of female-bodied individuals that act and identify as women and are attracted to their counterparts; male-bodied individuals with a masculine behavior, who are yet again attracted to their polar opposites. While this may seem like a nature-given system, we are in fact dealing with the result of a historical process in which the logic of biological taxonomies has penetrated our understanding of identity. ${ }^{8}$

Female impersonation has arguably entered mainstream culture and is not generally perceived as offensive to women (again, generally). Due perhaps

\footnotetext{
${ }^{4}$ See: Taylor, Verta \& Leila J. Rupp. "Chicks with dicks, Men in Dresses." Journal of Homosexuality.

${ }^{5}$ Ibid.

${ }^{6}$ Ibid.

${ }^{7}$ See: Butler, Judith. Gender Trouble.

${ }^{8}$ Ibid.
} 
in part to ongoing controversies in American society around what can be appropriated or subverted and by whom, the same cannot be said of performing race or culture. There are numerous recent occasions where pop performers or comedians have performed in or dressed in black or "yellow" face that were met with widespread criticism and repudiation. This is not surprising given US history and the complexities of race in US society, but the unintended consequence is that the performative nature of aspects of identity in American or other cultures beyond gender have not been as explored or experimented with to that same degree as the performative elements of gender. Yet there are performative elements associated with black, Latinx, Asian, or white American cultural identities that are exposed when the crossing of cultural boundaries changes the codes or meaning associated with race.

\section{A Brief Overview of Race, Culture, and Identity in American Performance}

While mimicry may be understood as a conscious statement or choice, the performative aspects of mainstream normative culture are assumed to be neutral. And yet this is the more dangerous assumption, as no performative choice is truly neutral or devoid of meaning.

White Americans may have an ambiguous relationship with the performance of identity and mimicry. The history of performing race, culture and identity reveals how the performance of 'the other' historically has been constructed from a white perspective that they have been central in establishing clear boundaries around those in power thus supporting the hegemony of whiteness.

Any attempt to summarize a subject as broad and complex as the history of and discourse on the performance of identity in American culture risks being cursory at best. It is, nevertheless, useful to have an understanding of some of the overarching questions and controversies that remain to a large degree contested and unresolved, and to compare some of the seminal stereotypes, works, and artists who are emblematic of specific identities.

Theatrical performance has had a unique historical role in challenging and exploring the performance of American identity. In theatre, the body, by definition, becomes a site to perform, contest, subvert, and reinforce meaning. The performance of race and identity in American theatre, particularly in the $20^{\text {th }}$ century, has been complicated and controversial, arguably serving an 
important role in broader conversations about gender, race, and sexuality in American society. ${ }^{9}$

Brandi Wilkins Catanese observes that "performance has become the medium through which American Anxieties about race (and in particular, blackness) are pondered, articulated, managed, and challenged.” 10 The performance of American identity has, in fact, a uniquely racialized history. In his book Theatre and Race (2013), Harvey Young discusses the significance of the legacy of blackface performance, proclaiming it "the most spectacular theatrical genre involving the staging of race and racial difference.” He traces the practice of using stage makeup to perform black characters via the portrayal of "Moors" in $16^{\text {th }}$ century British drama and the performance of the harlequin figure in Italian commedia dell'arte to the nineteenth-century when American theatres featured minstrel shows. A practice that did not end until the Civil Rights Movements in 1960s. ${ }^{11}$

Young points out that "blackface performance, by the end of the nineteenth century, had become the first significant and uniquely American contribution to global performance." 12 In other words, the performance of race became the defining feature of the export of American identity. Young asserts that blackface minstrel shows "relayed a sense of the dramatically interesting dynamic involving race in the country." 13 The by the mid to late $20^{\text {th }}$ century, African American theatre companies had found their place and played a critical role in developing and staging black stories and works. ${ }^{14}$

The late $20^{\text {th }}$ century saw the eventual eradication of the performance of "black face," and while it remains arguably the most pervasive and prominent example of the racialized performance of American identity, it is by no means the only example.

The performance of Native American identity, or "redface," is not only still tolerated, it remains integral to thousands of stagings of the Thanksgiving story by American schoolchildren every year. And while the performance rarely includes the actual makeup, the plays tend to locate race in the binary of the "pilgrims" vs the "Indians." Redface performance was also central to a seminal

\footnotetext{
${ }^{9}$ For useful reading on race and gender performance in American theatre see: Sue-Ellen Case, Performing Feminisms: Feminist Critical Theory and Theatre, in addition to Demastes and Smith Fischer, Interrogating America, and Uno and San Pablo Burns, The Color of Theater.

${ }^{10}$ See: Brandi Wilkins Catanese, Problem of the Color[blind]: Racial Transgression and the Politics of Black Performance.

${ }^{11}$ See: Harvey Young, Theatre \& Race, p. p. 36..

${ }^{12}$ Ibid.

${ }^{13}$ Ibid.

${ }^{14}$ Ibid.
} 
moment in American history, as colonists costumed as Native Americans to stage the” Boston Tea Party" protesting British taxation without representation.

Performance of the Native American identity was popular in early American dramas staging stories of Westward expansion. White actors used dark makeup to alter their appearance. The portrayal of Native Americans became particularly prominent with the emergence of film. The dominant popularity of "the Western" genre in early American cinema required the constant performance of Native American stereotypes and exaggerated "savages," not as Americans, but instead as a constant threat to the American heroes. These characters almost exclusively played by white actors using darkened makeup and wigs with long braids. Costumes were amalgamations of specific tribal costumes and buckskin, with no consideration of lived practice..$^{15}$

This is similar to the coalescing effect of Asian "yellowface" performance. Yellowface performance in American is noteworthy in its endurance. Eradication of the performance of blackface did not translate to eradication of yellowface, which remained in practice to varying degrees until the late 1980s, when the casting of British actor Jonathan Pryce in the lead role in Miss Saigon led to protests, boycotts, and repudiation within the Broadway acting community.

In his book Latin Numbers: Playing Latin in Twentieth-Century U.S. Popular Performance ${ }^{16}$, Brian Eugenio Herrera chronicles and interrogates the history of the performance of Latino/a identity in the U.S. He details the trajectory from specific culturally distinctive groups such as Mexican, Puerto Rican, and Cuban at the beginning of the $20^{\text {th }}$ century to broad and diverse categories such as Hispanic and Latinx by the end of the century. While Herrera acknowledges that Latinx identities are less racially apparent than the ones of Black or Asian individuals he is still able to examine "popular performance", in this context practices and material products within expressive culture that are animated by the performer's voice, body and words and intended for mass consumption. ${ }^{17} \mathrm{~A}$ focus of his is the popularity of music and nightclub performance of tango and conga in the 1940s and 1950s, as a major influences in emergent perceptions and representations of a Hispanic identity.

In either case, Asian and Hispanic American theatre movements share an additional layer of complexity in that both classifications are artificial and contested. There are, for instance, Chinese American and Cuban American

\footnotetext{
${ }^{15} \mathrm{Ibid}$, pp. 48-51.

${ }^{16}$ See: Herrera, Brian Eugenio, Latin Numbers: Playing Latino in Twentieth-Century U.S. Popular Performance.

${ }^{17}$ Ibid,p. 9.
} 
theatre companies who prioritize actors of those specific heritages over other members of the broader culture group they might otherwise identify with.

A discussion of the performance of race in American theatre would be remiss to ignore the performance "whiteness" or to acknowledge it as an equally racialized performance. In her book, The Problem of the Color/blind]: Racial Transgression and the Politics of Black Performance (2011), Brandi Wilkins Catanese challenges "the silent conflation of whiteness with Americanness." 18 Perhaps because of the dominance of the white-American perspective in the dramatic canon, the performance of whiteness has not been actively interrogated and has, in fact, been privileged as the racial performance to which all others are in opposition. Catanese theorizes that, "multiculturalism was in part a response to the fact that lopsided representation of American society normalized whiteness by making other racial groups (and by extension cultures) invisible.”19

Angela Pao states the obvious but also gets to the heart of the complexity of performing identity by pointing out that any performance forces "two more or less fully constituted identities - that of the actor and that of the character - to inhabit the same body." 20 The identity associated with the actor's body, whether racial or gender, pre-exists the performance, as does the character they portray.

\section{Moving Beyond Authenticity of Culture}

It is important that we as international educators provide a clear framing of culture. Culture is currently used about an eclectic range of phenomenon covering mentality, folklore and highbrow culture as well as appearance and embodied practices: the discourse often assumes that these are closely connected and that they emerged spontaneously and organically, and furthermore that they reflect an essence of the people who use and perform them. Instead we must diffuse the elements and realize that social identity is the result of positionality and action rather than essence. At the same time, we need to remind our students that while these identities are socially constructed, they are very real to those who are subject to them, and that it can have consequences to challenge their worldviews.

The Italian scholar Umberto Eco notes that the American imagination demands the real thing, ${ }^{21}$ and study abroad is not exempt from the romantic notion of the authentic. ${ }^{22}$ Here the term seems to be rooted in a colonial

${ }^{18}$ Catanese, 2014, p.17.

${ }^{19}$ Ibid, p. 6.

20 Pao, Angela C., No Safe Spaces. Re-casting Race, Ethnicity, and Nationality in American Theater, p. 23.

${ }^{21}$ See: Kooijman, Jaap, Fabricating the Absolute Fake. America in Contemporary Pop Culture.

${ }^{22}$ See also: Johnson, Martha, Post-reciprocity: In Defense of the "Post" Perspective, Frontiers: The Interdisciplinary Journal of Study Abroad. 
mythology about the noble savage in which the analogue, primitive, and rural is more real than the urban, and that which has been contaminated by globalized capitalism. ${ }^{23}$ This notion of authenticity is however both out of touch with the world our students find themselves in and the lived experiences of inhabitants of the places they visit. Students currently going abroad will often find themselves at franchises of multinational companies. While they appear American, and generic, they also serve as the meeting places for local youth cultures, and the venues are thus integrated into their local communities. ${ }^{24}$ The Dutch media scholar Jaap Kooijman, who is preoccupied with how culture is performed in postmodern society, mirrors this observation. His book Fabricating the Absolute Fake examines the complicated relationship between Dutch and American mass culture. Building on Roland Robertson's term glocalization he argues that the material and cultural make-up of the glocalized world is one in which a uniform mode of consumption characterizes societies. ${ }^{25}$ This does however not mean that cultures necessarily have become more homogenous but rather that there is space for a redefinition of consumer products in the local context. This breaks with the idea of consumers as passive subjects that are fed American mass culture. They are rather active in the appropriation and the following redefinition of the products they consume ${ }^{26}$.

The idea of the authentic or essential is central to the western discourse around national culture and it shares a number of similarities with the discourse around gender. The discourse of national culture is reflected within study abroad where there is a strong focus on cultures organized in a dialectic system between us and them. ${ }^{27}$ It is through the encounter with the other that the sending culture comes into existence, or said in more mundane terms, that students gain an awareness of their own culture when confronted with the other. This discourse assumes that culture is so habitual that we need an antithesis to define it up against in order to discover that we have it. Scholars of national identity suggest otherwise. Their research indicates that people in the west are very aware of belonging to nations and of the culture that follows even prior to being exposed to other cultures. Benedict Anderson, ${ }^{28}$ Ernest Gellner ${ }^{29}$ and other scholars preoccupied with the formation of national identity in the West have demonstrated how the idea of belonging to a nation emerges in the early modern period and how the idea is consolidated through modernity. Anderson remarks that citizens within nations grow to imagine themselves as connected

\footnotetext{
${ }^{23}$ For an example of this discussion, see: West, Harry G. "Artisanal Foods and the Cultural Economy: Perspectives on Craft, Heritage, Authenticity and Reconnection."

${ }^{24}$ Johnson, 2015.

${ }^{25}$ You will find a similar discussion in: Augé, Marc, Non-places. An introduction to Super Modernity.

${ }^{26}$ For a similar argument relating to study abroad, see: Johnson, 2015.

27 See: Billig, Michael, Banal Nationalism.

${ }^{28}$ See: Anderson, Benedict. Imagined Communities. Reflections on the Origin and Spread of Nationalism.

${ }^{29}$ See: Gellner, Ernest, Nations and Nationalism.
} 
with other people of that particular nation, even though they have never met each other, or even heard of their existence for that matter. He observes how 'the people of the nation' or said in another way, bodies subjected to the power of a specific state, learn to imagine themselves as a community through linguistic standardization as well as bureaucratic control, and stories and myths often underlying a specific identity and culture as well as marking an 'other' to define the nation against. The result being that specific bodies started thinking a specific way about themselves and got to understand their behavior as specific to nation. Said in simple terms; bodies, thoughts, and behaviors were fused, and they were connected with strong feelings. These power structures have an uncanny resemblance to the structures that shaped the modern understanding of sex, gender, and sexuality, and are equally performative.

The idea of a national culture has been a convenient narrative for nation states when justifying their existence. While often having been institutionalized top down, the narratives have been internalized by the citizens of the various nations and they now help reproducing it on a daily basis. ${ }^{30}$ This is demonstrated by the British scholar Michael Billig who shows how we reproduce national identity through banal daily actions and symbols. ${ }^{31}$ The internalization of national identity by the subjects of the nation state has resulted in an alignment of the national project and the identity of the individual. That means that we often will find the same narratives when we examine people within a nation as we would when looking at normative sources, or said in another way, there is often an overlap between descriptive and prescriptive sources, or in short that there is a real way of belonging to the imagined community of the nation. Here we observe a strong parallel to the construction of gender.

\section{Cultural Drag Goes Abroad}

The idea of culture as vested in performative acts is central to Jaap Koijmann's analysis of postmodern society. He takes his port of departure in the adaptation of Thomas Elsaesser's metaphor of karaoke and thus turns the performance of culture into a doubly coded space of identity as overlap and deferral, as compliment and camouflage. ${ }^{32}$ While this article is inspired by Koijmann's approach it uses drag as a mode of understanding the performance of identity in a study abroad setting. Karaoke and drag share a number of similarities. Both genres are first and foremost performative, which means that both are based in actions, and that they are embodied practices in which one commands a gaze. Drag also operates in a field of mimicry, satire, and

${ }^{30}$ Billig, 1995.

${ }^{31}$ Ibid.

32 Kooijmaan, 2013. 
compliment. Drag is, however, freer than karaoke, as this performance leaves room for improvisation. It is also more dangerous as the person doing drag bends their social identity and thus takes the risk of breaking social conventions, which can lead to sanctions in the form of social exclusion and in some cases violence.

Jossiannia Arroyo uses the term "cultural drag" in her essay "Mirror, Mirror on the Wall:" Performing Racial and Gender Identities in Javier Cardona's "You Don't Look Like." She suggests that the term "constitutes itself as the "performance" of other cultural, sociopolitical, and subjective order such as race, class, gender and sexuality." There is a difference, however, as she is still defining the term within gender performance, although doing so within the specifics of performing Puerto Rican female identities.

For our purposes, we are focusing on the primacy of culture as the subject of performance rather than gender. Indeed, these two identities are often intersectional, however the performance of culture can and does operate beyond the boundaries of gender.

A similar definition of cultural drag is found in Cultural Drag: Theorizing the Performance of Non-native Spanish Teachers' Linguistic and Cultural Identities by the American scholar Jennifer Wooten. ${ }^{33}$ Wooten describes how she as a teacher of Spanish has had to construct a hyperbolic character with an affected way of speaking, moving and dressing. She also describes how teachers of foreign language facilitate the cultural performance of their students in the classroom. Wooten argues that cultural drag, not only, names the performative process by which linguistic and cultural identities are constructed but also that it offers analytic possibilities regarding said identities. ${ }^{34}$ While Wooten's mainly is occupied with the way identity is performed by non-native speakers who either learn or teach a language, she does consult scholars who have dealt with the performance of race, class, gender, and sexuality on stage. ${ }^{35}$ The analogy is similar to that of language learning, and foreign language acquisition often is an element in study abroad, however there are some slight differences. The study abroad experience is, to a much larger extent, an embodied experience and the suspension of disbelief that can be staged in the classroom is harder to take for granted in a foreign setting. Wooten does touch upon the study abroad experience in her analysis of L. Tharp's Kinky gazpacho: Life, love \& Spain and Tharp's costuming upon her arrival in Salamanca. ${ }^{36}$ The strength of this

\footnotetext{
${ }^{33}$ Wooten, 2010.

${ }^{34}$ Ibid, pp. 15.

${ }^{35}$ For example: Arroyu, 2002

${ }^{36}$ Wooten, (2010, p. 38
} 
analysis is that it in fact addresses how some bodies are privileged in the process of passing over others. ${ }^{37}$ This point will be explored further in the present article.

The notion that study abroad that practitioners encourage their students to engage in cultural drag is not new, but the conscious application of the performative framework is. ${ }^{38}$ Students are often told to dress in a certain way, and overall adapt their behavior according to notions about the specific nation that are considered authentic. Students are introduced to traditional food, folklore, and local highbrow culture, often disregarding everyday practices of the locals or radical alterations in political and social realities ${ }^{39}$. The belief is that this culturally sensitive behavior will make students grow and make them aware of cultural differences. While practical when helping students understand contemporary identity politics and elements of cultural histories, it may not be the most accurate way of describing the place that students find themselves in. It, first of all, downplays the composite nature and diversity of nation states, but it also leaves little room for understanding individuals as more than just the place they are from. It furthermore tends to focus on differences in the encounter with the people at the destination students go to and can thus contribute to a feeling of being othered. We could call this the negative side of cultural drag. The stylized performance of culture often tends towards stereotype and fetish. Singular elements of dress or style are ascribed epistemological meaning beyond their importance or authority. Kimonos, lederhosen, and cowboy hats are all examples of costumes that have powerful cultural associations despite varying levels of use or authenticity - similar to cultural appropriation this is a form of mimicry that reduces culture to essence.

As students going abroad are considering and engaging with their identity and navigating the nuances of stereotype, imagery, and performance on a daily basis they are suddenly hyperaware of their appearance and aspects of their physicalities, (race, height, hair color and texture) to a degree they may have not been before. This awareness of their positionality and performativity affords an opportunity to help them explore their identity and the implications of its performative aspects, for some, for the first time.

Additionally, outside of the US context there is a fluidity to cultural performance that is not possible within the US. A Caucasian student in Japan might be encouraged to wear a kimono, but if the same student wore the same costume to a Halloween party in the US, they would be likely to be accused of cultural appropriation. The liminal spaces abroad, the location in another

\footnotetext{
${ }^{37}$ Ibid., p. 43.

${ }^{38}$ Johnson, 2015.

${ }^{39}$ Wooten (2010) has a similar discussion about the staging of national culture in foreign language classes.
} 
country, allows for an exploration of the performance of culture that holds potential to be taboo in the US.

Parallel with this prescriptive cultural performativity we can observe that students themselves engage in a continuous act of mimicry while being abroad both in terms of language learning but also literally mimicry. This could be in the form of a change in their sartorial practices. This field has never been subject to research before but there are related fields in which the costuming of the explorer has been explored. The Swedish scholar Torun Elserud has researched how female backpackers costume themselves in order to perform the role of the explorer. She notes that 'The aesthetic appearance is an important aspect of the adventure identity'. ${ }^{40}$ Travelers combine costuming with location specific behaviors so that they fit in with other travelers and/or locals, but also so that they can tell a story about their travels upon their return. ${ }^{41}$ If this is similar to the motivations that move study abroad students to change their appearance while abroad, we have missed an important aspect of the formation of identity in our advising.

Elserud notes that her informants are aware of the constructed nature of their appearance and behaviors and that they ironically will talk about the way they have assembled their looks. This, not only, transforms them from passive consumers to active producers of their identity, but also avoids the trap of essentializing identity. Instead, it becomes the plastic result of a continuous series of acts. Or said simply, if identity is vested in embodied actions rather than in an essential form of being, it becomes something which is open for active experimentation. It also opens up for a discussion of the potential for learning experiences during and after students have been abroad as well as a discussion of the possible venues for learning.

\section{Cultural Drag as an Embodied Practice}

Reading advertisements for study abroad could lead one to believe that the first step of the experience is a decapitation, in which the body in stored away back home and the head is sent to an exotic destination. Websites often boast of academic gains, deep learning, and personal growth. While we all hope for this, it downplays that the defining trait in international education is that the body is moved from its usual location and that the location is central for the learning acquired. This section argues that the body is central to the experiences students have while abroad and that fostering an awareness of embodied practices around performance of culture hosts the potential for deep learning.

\footnotetext{
${ }^{40}$ See: Elserud, Torun, Gender Creation in Travelling, or the Art of Transforming an "Adventuress." ${ }^{41}$ Ibid.
} 
In traditional Western thinking, we see the body as merely the vessel in which the mind travels. This draws on the preconceived notion that there is a distinction between the body and the mind, almost as if the two exist independently. While modern science most likely will enable the existence of the two as independent entities at some point, we need to accept that the body, currently, is not an accessory. This realization is central to the philosophical discipline phenomenology. It is a philosophical system concerned with perception. Within phenomenology, the focus is not on an outside or objective reality, but rather on the way we understand and interact with the world around us. It does not deny that there is an objective, we can call it scientific truth, rather there is an understanding of the fact that what we sense is not necessarily what is. However, what we sense, becomes our truth. ${ }^{42}$

Within phenomenology we work with the notion that there is a preunderstanding when we perceive, a mental and physical filter that stands between us and the world. That filter is the body. Different bodies will thus have different lived experiences and interpretations of these experiences. We call this the 'lifeworld'. At the same time, different experiences will lead to different bodily practices - a habitual somatic knowledge. This knowledge is neither thematic, nor involuntary action. It is pre-reflected; we could call it operative intentionality. One such example is the act of finding your way in a familiar environment. The body knows how to navigate the space. It is almost as if the space is an extension of the body. The lived body is thus both material and selfconscious. There is a mind in the body and a body in the mind. ${ }^{43}$

The French phenomenologist Henri Lefebvre states that modernity has brought about a decorporealization of knowledge. He states that this creates a bias against how we examine our bodies in the world, and the world through our bodies. We simply favor academic knowledge over experiential knowledge. Lefebvre compares the verbs savoir and connaitre. Interestingly, they both translate as the English verb to know. The French verb, savoir, covers formalized and institutionalized knowledge. We know a circle as a geometrical concept with a radius, that measures the same from the center to the edge, regardless of the direction. This type of knowledge is often produced by those who hold power, and thus becomes not just a representation of power but also a measure of control, which helps us distinguish right from wrong. While this knowledge certainly is useful, it does not necessarily match the less formal private form of knowing held by the individual, connaitre, a verb that connotes a relationship. If we return to the circle, one can understand the round shape without understanding the formalized description of the concept circle. We

\footnotetext{
${ }^{42}$ See: Merlau-Ponty, Maurice, Phenomenology of Perception.

${ }^{43}$ Steward, Lynn; Bodies, Visions, and Spacial Politics: A review essay of Henri Lefevbre's The Production of space.
} 
have all experienced something round - few of us would however be able to explain the circle as a geometrical phenomenon. ${ }^{44}$

The current discourse within study abroad is one that emphasizes cultural learning which can be standardized, quantified, and measured. It assumes that cultural competences follow the logic of academia and that it can be graded accordingly. While we in some cases talk to our students about dressing according to local customs, we rarely address the embodied experience of being present, nor do we address the way the appearance of the individual student may affect the study abroad experience. This bias ignores that certain bodies are privileged over others in the encounter with the other.

Returning to the metaphor of drag, we can consider the term realness. Basically, how well a drag queen emulates the gender role 'woman.' We can compare this to the experience of students passing for locals and the privileges that follow, or the challenges that comes with not sticking out. This is to a degree dependent on the body students travel in, but it can be negotiated through costuming and the adaptation of specific mannerisms. Similarly, there is potential for a discussion with students about how they can experiment with their identity while abroad, and how the experimentation may open up for learning experiences. It is not suggested that we try to convince students that they will have an authentic experience by changing their dress or their mannerisms, but rather that they can monitor how a change in their appearance and behavior changes their reception and perception.

The connection between costuming and culture has already been made in advising practices but not explicitly as cultural drag. It is considered standard advising practice that students are provided with information on appropriate attire for internships or gender-based norms for covering cleavage or shoulders. By using the framework of cultural performance, the meanings imbedded in the various choices can be interrogated. Similarly, we can consider what happens when the illusion of cultural drag fails, that could be when students fail to perform according to local norms, or when someone who looks the part does not speak the local language or speaks it with an accent. Cultural drag in its extremes devolves to cliché and stereotype, but the framework of positioning culture as performance allows for better observation of its subtleties. Students often ask "how do they know we are American? And even beyond the more obvious dead giveaways of white tennis shoes or baseball caps, is there a confidence in movement, a tenor of voice, a pitch and volume of laughter, that are particularly culturally American? Are they performing their culture whether or not they intend to or not?

${ }^{44}$ Steward, 1994. 
Another strength of the ongoing experimentation with performed identity is that it may lead to other intimate learning experiences. The British fashion scholar Joanne Entwistle has written extensively on the embodied experience of wearing clothes. She finds that while dress is essential when establishing order in social environments, it has often been neglected by sociologists. Entwistle sees the body as a highly restricted medium of expression in the sense that it always situated in a spatial and temporal context. ${ }^{45}$ The body will thus engage in a continual exchange of meanings with its surroundings and the mind in the body will experience thoughts and feelings based on this. Basically, that the body is not just a socially constituted object but also the site of social and personal identity. ${ }^{46}$ Students will thus be able to monitor their interaction with the social space around them and how it may change depending on their costuming and behavior. While this may not give a deep insight into the mentality of the one students are emulating, it has the potential to reveal a number of power structures in the given context.

As practitioners, we need to consider our advising and how biases around appearance and performance may reinforce power structures. Certain bodies may hold privilege over other bodies in the act of cultural drag. Someone who passes as a local will have a different experience of moving through a space and thus have the potential to interpret an experience differently from someone who does not pass. The one who passes will, however, not necessarily get a deeper understanding of what it is like to be a local. Mimicking a culture does not give you lived experience of being from a place. Therefore, if we examine their interpretation, it is not more or less right than someone who does not pass. What we can conclude is merely that the position from which they have made their observations has affected them.

Similarly, we need to break down the experience students have abroad as well as the way they handle the challenges they meet. We need a nuanced approach because our student body is diverse and therefore enters the experience from different starting points. The positionality of experience opens for a dialogue in which the experience is unpacked and contextualized by formalized knowledge, but also where the constructed nature of this formalized knowledge can be critiqued and disassembled.

The reality of the response their body elicits can result, for many students, in identity fatigue. The variations of this are numerous and complex. The African American student who can't get a haircut or treatment, the Asian American student constantly asked to negotiate with taxis for the group in Asia

\footnotetext{
${ }^{45}$ See: Entwistle, Joanne. Fashion and the Fleshy Body: Dress as Embodied Practice, Fashion Theory. The Journal of Dress, Body, and Culture. ${ }^{46}$ Ibid.
} 
to get a better fare, or the tall blonde Minnesotan of Norwegian descent whose hair is constantly touched in Africa. The experience of either first-time physical otherness or on the other end of the spectrum first-time physical anonymity evokes complex responses from frustration and fear to relief. In an American climate that increasingly educates individuals and prepares them to advocate for their identities. It is critical that student support teams and instructors understand the psychological impact of the physical experience and help students find strategies to cope or navigate. This is particularly critical when the epistemology of the body, or its meaning, is dramatically different in the host culture. Culture and beauty norms around skin tone, weight, height, or hair differ vastly from culture to culture, but the student is often unprepared or ignorant of the code their body represents.

The tradition of study abroad in the US context has developed from a primarily white, privileged perspective, with a discourse based in colonial notions of discovery, exploration, and subjection. The American student goes abroad on a contemporary version of the "grand tour" or in search of the exotic. Study abroad marketing materials are littered with problematic promises including "immersion" and encounters with "the real." This tradition and metanarrative include a privileging of the white, male body in many locations, particularly in the post-colonial world. In Gender Trouble, Judith Butler points out that "the body often appears to be a passive medium that is signified by an inscription from a cultural source." ${ }^{\prime 7}$ But who's cultural source is dominant in a given location?

Whiteness is not a category that white students are likely to have considered or interrogated in advance of going abroad, never having been "the other." A response to their body from a racial perspective may be confusing or threatening and is often not something they have consciously considered before. Intersectionality, or association with multiple, often marginalized, identities can complicate experiences as well. The response an African American female elicits on the street in Spain is frightening and particularly confusing, as it might relate to her identities as both a female and a person of color. Indeed, in her book Gender Trouble, Judith Butler is careful to point out that "racial presumptions invariably underwrite the discourse on gender in ways that need to be made explicit, but race and gender ought not to be treated as simple analogies." ${ }^{\prime 4}$ In other words, gender is never adequate as an exclusive category of analysis.

Difference comes with either benefits and/or disadvantages, and perhaps often both. As we seek to improve our work around inclusion, it becomes an imperative to move beyond study abroad for the mind and the heart,

${ }^{47}$ See: Butler, 1990.

${ }^{48}$ Ibid., p. XVI. 
to better acknowledge and prepare students for the physical experience of the body abroad.

Finally, there is a need for us to recognize the way students inscribe their study abroad experience onto their bodies, in some cases quite literally. This could be in the form of tattoos or by adopting a given sartorial practice upon their return to their home campuses. Again, we are dealing with a performance that is highly communicative. One in which students may wish to signal that they have changed or that they differ from their peers. ${ }^{49}$

We travel in our bodies. This states the obvious and yet the majority of our preparation, facilitation, education, and reflection in education abroad is based in the mind. We prepare students to think, feel, reflect on their experience but most of us do very little to prepare them for the physical experience of going abroad. In fact, much of the preparation for encounters related to the body tend to assume the body to be that of a white, perhaps female, student. While that perhaps was sufficient in the past, it will not be so for the future.

For many students, going abroad may be the first time they actually realize they travel in a body. The opportunity is suddenly available to engage with students who find themselves in the new liminal space of understanding they have a body, and perhaps experiencing racial, cultural, or gender discomfort for the first time. That palatable discomfort and desire to costume and "pass" as quickly as they can exposes the instinctual anxiety they have, intuiting that they do not fit in and are suddenly the other.

For students who have never had this experience in the US, the opportunity for growth is enormous, but often goes unexplored or discussed in a framework that acknowledges the physical dimension of experience. By developing exercises or reflections in our program design that incorporate consideration of the physical and performative dimensions of experiencing a new place, educators can support students in a new dimension of understanding.

This article suggests that operationalizing the term cultural drag hosts great potential in this regard as is recognizes identity as embodied, performative as well as plastic. By recognizing that the body is not just a vessel that the mind travels in, but an active interface between the sensing self and the world, we reveal that the body performs culture. We also show that the way the body acts and behaves has potential to change the relationship with a social space, so that we can uncover biases about, not just the body itself, but also its place in the world. We discover that the body is not just a biological entity, but a unit that is a part of the more complex and multifaceted organism that is the world. The body has culture, does culture and is subject to culture. It is a sensing, moving,

${ }^{49}$ For a similar discussion, see: Elserud (2006). 
and learning being. It is only when we understand and accept this that we will be vulnerable to the full potential of study abroad.

\section{References}

Anderson, Benedict, Imagined Communities. Reflections on the Origin and Spread of Nationalism. Verso, 1983.

Arroyo, J., "Mirror, mirror on the wall": Performing racial and gender identities in Javier Cardona's "You don't look like", The State of Latino theater in the United States: Hybridity, transculturation, and identity, edited by L.A. Ramos-Garcia. Routledge, 2002.

Augé, Marc, Non-places. An introduction to Super Modernity. Verso, 1992.

Billig, Michael, Banal Nationalism. Sage Publications, 1995.

Butler, Judith, Gender Trouble. Routledge, 1990.

Case, Sue-Ellen. Performing Feminisms: Feminist Critical Theory and Theatre. Johns Hopkins University Press, 1997.

Catanese, Brandi Wilkins, Problem of the Color[blind]: Racial Transgression and the Politics of Black Performance. University of Michigan Press, 2014.

Demastes and Smith Fischer, Interrogating America, in Uno and San Pablo Burns, The Color of Theater .

Elserud, Torun, "Gender Creation in Travelling, or the Art of Transforming an "Adventuress”," Tourism, Consumption, and Representation. Narratives of Place and Self, edited by Methan, Kevin, Anderson, Alison, Miles, Steve. Cambridge, 2006.

Entwistle, Joanne. Fashion and the Fleshy Body: Dress as Embodied Practice, Fashion Theory. The Journal of Dress, Body, and Culture, vol. 4, iss. 3, 2015, pp. 323-347.

Gellner, Ernest, Nations and Nationalism. Cornell University Press, 1983.

Herrera, Brian Eugenio. Latin Numbers: Playing Latino in Twentieth-Century U.S. Popular Performance. University of Michigan, 2015.

Johnson, Martha. "Post-reciprocity: In Defense of the 'Post' Perspective," Frontiers: The Interdisciplinary Journal of Study Abroad, vol. 18, 2009, pp. 181-186.

Kooijman, Jaap. Fabricating the Absolute Fake. America in Contemporary Pop Culture. Amsterdam University Press, 2013.

Merlau-Ponty, Maurice. Phenomenology of Perception. Routledge \& Kegan, 1962.

Ogden, Anthony. "View from the Verandah: Understanding Today's Colonial Student." Frontiers: The Interdisciplinary Journal of Study Abroad, vol. 15. 2008. 35-55.

Pao, Angela C. No Safe Spaces. Re-casting Race, Ethnicity, and Nationality in American Theater. University of Michigan Press, 2011.

Steward, Lynn. Bodies, Visions, and Spacial Politics: A review essay of Henri Lefebvre's The Production of Space. University of British Columbia, 1994.

Taylor, Verta \& Leila J. Rupp. "Chicks with dicks, Men in Dresses," Journal of Homosexuality, vol. 46, iss. 3-4, 2004, pp. 113-133.

West, Harry G. "Artisanal Foods and the Cultural Economy: Perspectives on Craft, Heritage, Authenticity and Reconnection." The Handbook of Food and Anthropology, edited by Jakob A. Klein \& James L. Watson. Bloomsbury Academic, 2016. Wooten, Jennifer A., Cultural Drag: Theorizing the Performance of Non-native Spanish Teachers' Linguistic and Cultural Identities. Georgia, 2010.

Young, Harvey. Theatre \& Race. Palgrave Macmillan, 2013. 


\section{Author Biographies}

Dr. Martha Johnson is the Assistant Dean for Learning Abroad at the University of Minnesota. She has worked in international education since 1991 for organizations in the US, Ireland, Australia, and the United Kingdom. She holds a BA in English literature and theatre arts from St Mary's University of Minnesota, an MA in English literature from University of St Thomas, and a PhD in American Studies with an emphasis in drama and the performance of gender, race, and cultural identity from the University of East Anglia, UK.

Anders Larsen, Cand. Mag. has a background in cultural studies. He is specialized in the formation of contemporary national identities in Europe. For the past decade he has been working in international education at DIS - Study Abroad in Scandinavia. His work has focused on the cultural experiences of students, but he has also been teaching various classes within cultural history and visual culture. Anders is a seasoned drag performer. 